\title{
Parks in transition: adapting to a changing world
}

\author{
BRIAN A. CHILD
}

Parks have evolved far more than commonly supposed, adapting to changes in society. Although they are largely associated with the so-called Yellowstone model, providing public access and outdoor recreation (Schelhas, 2001), new sustainable use and private and community conservation models already account for a third of global protected area. We see the evolution of protected-area concepts in the themes of the World Parks Congresses: definitions and standards (1962), ecosystems (1972), sustainable development (1982), global change and management effectiveness (1992), governance, financing, landscapes and benefit sharing (2003), and justice and adaptability (2014).

In this issue Dudley et al. (2014) recognize that protected areas are becoming 'more complex in concept and more complicated in management'. They describe six major changes that have occurred in the last 2 decades, begging the question: what is the business of protected areas and what should it be? Who are parks for (the political question), what are they for (the technical question), and how do we get there (the operational question)? Murphree (2002) suggested that protected areas are a form of collective action that provides a full range of nature-based benefits for society, one of which is sustaining nature. The national parks concept is well-aligned with the needs of modern urbanized societies, but an evolution of the model is required to align it with impoverished rural neighbours in developing countries where parks are under extreme pressure.

Protected areas are immensely valuable to society, including to people who live locally to such areas. There is clear evidence of this in Europe and North America but in developing countries benefits tend to skip over local people, to be captured by elites. Nevertheless, neighbouring communities usually value and want protected areas for reasons ranging from enhanced rainfall (Hartter \& Goldman, 2011) to employment, although these values can be undermined by bitterness towards park managers and the de-legitimization of traditional livelihoods such as hunting and gathering. Instead of defining conservation as a battle between righteous conservationists and greedy people, we need to align the goals of protected areas more closely with society and local people.

There are significant opportunities to enhance and promote the values of protected areas, and wild resources in buffer zones, and to reconfigure governance so that local people become the primary custodians and beneficiaries. The simple fact is that resources that are owned replace resources that are not; only $4 \%$ of global zoomass remains in wild species (Smil, 2011). To reverse this we need to develop new forms

Brian A. ChILD Department of Geography, University of Florida, Gainsville, Florida, USA. E-mail bchild@ufl.edu of ownership and beneficiation for wild species and ecosystems. The 'plurality of governance models' discussed by Dudley et al. shows that the search for new forms of ownership of nature that include private landholders and local people has begun.

Dudley et al. are tentative about the wider benefits of protected areas, and concerned that benefits don't filter down, particularly where governance is weak. We should be more confident about the economic value of protected areas, and also more responsible in ensuring that they benefit local people. Many protected areas have considerable value, financial and non-financial. Explicitly and pro-actively exploiting and devolving these values can fund parks and simultaneously address poverty. It is equally legitimate for African protected areas to provide jobs and economic growth as for North American parks to provide public access and outdoor recreation. The common value that binds us is protecting the integrity of the resource base, and we should not divide ourselves by bickering over cultural choices (Child, 2004). Thus, parks are governed by an efficiency equation: they should maximise social and private benefits (the numerator) with the essential constraint that ecosystem health and diversity is maintained (the denominator).

Embracing the economic value of parks will empower the protected-area movement. Politicians and policymakers often perceive parks as economic black holes but it is difficult to find a protected area that does not provide benefits that exceed costs, or that would do so if managed properly. The problem is that parks provide many benefits at the economic or societal level but are only analysed at the local or financial level. In Zambia, for example, Kafue National Park is inviable financially because annual gate fees of USD 650,000 don't cover annual management costs of USD 3 million. However, this park could easily generate USD 18-38 million annually in economic activity (and USD 3-7 million in tax alone) in addition to the value of millions of tons of carbon and the protection of the watershed.

Many parks cannot pay for themselves (although more can and should) but economically (i.e. from the perspective of society) they are still worth paying for. The literature justifying this contention is new, and tends to focus on valuation, which politicians and policy-makers view with scepticism, rather than value (jobs, income, foreign exchange, water supply), which has policy impact. Recent studies show that North American protected areas are 'longterm, vibrant economic drivers of local communities and regions', with 279 million visitors generating USD 30 billion in economic activity, 252,000 jobs and USD 13 billion in expenditure to communities within $100 \mathrm{~km}$ of the parks (National Park Service, 2013). Similarly, 'there is excellent evidence for 
the role of protected areas in poverty reduction in places such as Germany, Spain and the UK' (N. Dudley, pers. comm.). In Africa, with improved management practices, the same conclusions would emerge. State, private and community protected areas that support tourism or hunting can often pay for themselves (Suich \& Child, 2009) but more importantly they generate high economic returns in terms of growth, employment, economic multipliers, water supplies and carbon sequestration.

Parks, increasingly, are located amidst the poorest people. Rather than being defensive about the negative social impacts of this, we should promote parks as engines for sustainable economic growth at the forefront of the battle for poverty reduction and social justice. They often offer job opportunities in places where there are few alternatives. Parks can only become the cornerstone of conservation if they are proactively managed to promote the bio-experience economy over much larger landscapes. This worked in southern Africa, where bold policy reform flipped huge areas of land from the agro-extractive commodity economy to the biodiversity economy through the sustainable use of wildlife (Child et al., 2012). The argument that parks and wild resources have a comparative economic advantage that can be unlocked by directly addressing market failure is convincing to some policymakers, including international donors. UNDP's investment in protected areas in Africa (USD 90 million +270 million co-financing) and globally (USD 250 million +660 million) is increasingly based on making the economic case for biodiversity (N. Sekhram, pers. comm.).

Converting the high value of protected areas and wild resources into land-use incentives will require new economic rules, norms and practices. This takes us into the realm of governance. At the macro and global level new rules need to ensure that government, private and community landholders maximize the economic potential of wild resources and protected landscapes, and retain these benefits locally so they are not forced to replace wild resources with privately owned livestock, crops or plantations. At the micro level we need new forms of state, private, community and collaborative landscape governance to build larger bioeconomic landscapes.

Traditional state protected areas remain the cornerstone of such landscapes. Parks need to be properly funded through revenue retention and taxes. We need to question whether state management (as opposed to ownership) is ideal and to separate adequately funded and managed parks from so-called paper parks in global databases, to force us to improve management effectiveness of the latter.

The huge potential for private conservation requires legitimate stewardship arrangements that secure biodiversity, devolve ownership and increase bio-experience income. Community conservation is a subset of private conservation that faces particular challenges. The gap between the rhetoric and the reality of local devolution and empowerment can be addressed by non-transferable natural resource titles at the community level coupled with community governance models that avoid elite capture and ensure participation and equitable benefit-sharing. Community conservation works but only if certain principles are followed, presenting a case for an international compact that codifies the rights of local people to manage, use and sell their wild resources and to exclude others from doing so.

Finally, knitting parks and private and community conservation into biodiversity landscapes requires new forms of collective action to create significant economies and ecologies of scale. Tempting as it is to impose landscape conservation from above, only by building from the bottom do we strengthen critical public characteristics of local accountability and participation, or match the scale of functions to institutions (Murphree, 2000).

As we approach the 6th Parks Congress, how should the protected-area concept adapt, and where should we invest our intellectual and other capital? My argument is that our greatest return on investment lies in making the economic case for protected areas to society, and in maximizing the reinvestment of this value in effective management and local people. This will require new skills in protected-area economics and new models of protected-area governance.

\section{References}

Child, B.A. (ed.) (2004) Parks in Transition. Biodiversity, Rural Development and the Bottom Line. Earthscan, London, UK.

Child, B.A., Musengezi, J., Parent, G.D. \& Child, G.F.T. (2012) The economics and institutional economics of wildlife on private land in Africa. Pastoralism, 2, 18.

Dudley, N., Groves, C., Redford, K.H. \& Stolton, S. (2014) Where now for protected areas? Setting the stage for the 2014 World Parks Congress. Oryx, 48, 496-503.

Hartter, J. \& Goldman, A. (2011) Local responses to a forest park in western Uganda: alternative narratives on fortress conservation. Oryx, 45, 60-68.

Murphree, M. (200o) Boundaries and borders: the question of scale in the theory and practice of common property management. Presented at the Eighth Biennial Conference of the International Association for the Study of Common Property. Bloomington, Indiana, USA. Http://dlc.dlib.indiana.edu/dlc/handle/10535/1939 [accessed 28 August 2014].

Murphree, M.W. (2002) Protected areas and the commons. The Common Property Resource Digest, 60, 1-3.

National Park Service (2013) National parks serve as powerful economic engines for local communities, supporting 252,000 jobs. Http://home.nps.gov/news/release.htm?id=1440 [accessed 26 August 2014].

Schelhas, J. (2001) The USA national parks in international perspective: have we learned the wrong lesson? Environmental Conservation, 28, 300-304.

SMIL, V. (2011) Harvesting the biosphere: the human impact. Population and Development Review, 37, 613-636.

Suich, H. \& Child, B.A. (eds) (2009) Evolution and Innovation in Wildlife Conservation. Parks and Game Ranches to Transfrontier Conservation Areas. Earthscan, London, UK. 